\title{
HOUSING AND SECTION 1982: THE ADVISABILITY OF EXTENDING THE STATUTORY MANDATE BEYOND ACTS OF TRADITIONAL DISCRIMINATION
}

Ever since the Supreme Courts landmark decision in Jones $v$. Alfred $H$. Mayer Co., ${ }^{1}$ commentators have puzzled over the scope of the thirteenth amendment, both as to the rights it confers and the protection it affords those rights by the various federal statutes enacted pursuant to it. ${ }^{2}$ While Jones on its facts held merely that the thirteenth amendment, as implemented by section 1982 of the Civil Rights Act, ${ }^{3}$ forbids private sellers of real property to refuse to deal with otherwise qualified purchasers solely on the basis of race, ${ }^{4}$ the opinion indicated both that section 1982 would be construed liberally in the future ${ }^{5}$ and that Congress would be given wide latitude in drafting additional legislation designed to eliminate the "badges and incidents of slavery" which the amendment proscribes. ${ }^{6}$

This Note will deal with the judicial gloss which has been put upon section 1982 by two recent circuit court decisions involving housing discrimination, Clark v. Universal Builders, Inc. ${ }^{7}$ a Seventh Circuit decision, and Love v. DeCarlo Homes, Inc., ${ }^{8}$ decided by the Fifth Circuit.

THE FOLLOWING CITATION WILL BE USED IN THIS NOTE:

Note, Discriminatory Housing Markets, Racial Unconscionability, and Section 1988: The Contract Buyers League Case, 80 YALE L.J. 516 (1971) [hereinafter cited as Note, Contract Buyers].

1. 392 U.S. 409 (1968).

2. See, e.g., Kinoy, The Constitutional Right of Negro Freedom Revisited: Some First Thoughts on Jones v. Alfred H. Mayer Company, 22 RuTGERS L. REv. 537 (1968); Note, Jones v. Mayer: The Thirteenth Amendment and the Federal Anti-Discrimination Laws, 69 Colum. L. REv. 1019, 1023-27 (1969); Note, The New Thirteenth Amendment: A Preliminary Analysis, 82 HARV. L. REV. 1294 (1969).

3. 42 U.S.C. $\& 1982(1970)$.

4. 392 U.S. $409,421-22$ (1968). See text accompanying notes 35-38 infra.

5. Id.

6. $I d$. at 439-44. In Jones the Supreme Court expressly declined to discuss the extent to which the thirteenth amendment's self-executing directive that "[n]either slavery nor involuntary servitude . . . shall exist within the United States" operates to protect rights not presently guaranteed by statute. Id. at 439 . One commentator has suggested that the courts downplay the self-executing nature of the amendment and allow Congress, under authority of section two's enabling clause, "to reach more attennated practices which have the tendency to impose the 'badges' [of slavery] that may be reached by the courts." Note, The New Thirteenth Amendment, supra note 2, at 1319-20.

7. 501 F.2d 324 (7th Cir.), cert. denied, 43 U.S.L.W. 3349 (Dec. 16, 1974).

8. 482 F.2d 613 (5th Cir. 1973). 
Both cases addressed the issue of whether section 1982's guarantee that all citizens "have the same right . . . as is enjoyed by white citizens . . . to inherit, purchase, lease, sell, hold, and convey real . . . property" prohibits white real estate concerns from selling dwellings located in predominantly black residential areas to black purchasers at higher prices and upon more onerous terms than would be charged for similar dwellings located in predominantly white neighborhoods. The Seventh Circuit found a section 1982 violation; the Fifth did not. It is the thesis of this Note that the reasoning in neither case necessarily follows from the Supreme Court's pronouncements in Jones, and in addition, that the Seventh Circuit's expansive construction of the statute may have been ill-advised strictly from the standpoint of providing a practicable and even-handed remedy against the proscribed behavior for all subsequent owners of the properties involved.

\section{Clark and Love: Conflicting Conclusions From Similar Fact Situations}

Clark is the second ${ }^{10}$ appeal from a district court's disposition of issues arising from the Contract Buyers League litigation centered in the Chicago area. ${ }^{11}$ Suit was initiated by a class of black purchasers of newly constructed residences against the builders of the homes and various realty concerns which had actually sold thein. ${ }^{12}$ As explained by the court in Clark, the plaintiffs' theory for recovery was based on the allegation

that as a result of intense racial discrimination in Chicago and its metropolitan area there existed at all pertinent times a liousing market for whites and a separate housing market for blacks, the latter confined to a relatively small geographical area in the central city. Plaintiffs contended that the demand among blacks for housing greatly ex-

9. 42 US.C. $\S 1982$ (1970).

10. The first appeal was taken from the district court decisions in Clark and Contract Buyers League v. F \& F Inv., 300 F. Supp. 210 (N.D. IIl. 1969)-a companion case to Clark discussed in notes $12 \& 32$ infra. The appeal dealt with the running of the limitations period applicable to the alleged claims, and the lower court's holding in favor of the respective plaintiff classes was affirmed. Baker v. F \& F Inv., 420 F.2d 1191 (7th Cir.), cert. denied, 400 U.S. 821 (1970).

11. See citations to Chicago newspaper articles covering the events leading up to and immediately following the instigation of the Contract Buyers League class action in Note, Contract Buyers 521 n.12.

12. 501 F.2d at 327 . The first class action instituted by the League, Contract Buyers League v. F \& F Investment, 300 F. Supp. 210 (N.D. III. 1969), was brought by a class of black purchasers of used residential property against their sellers and the sellers' mortgagees. For an edited copy of the Contract Buyers League complaint, see S. Plager, New Approaches IN the Law of Property 112-25 (1970). The district court, while holding that the plaintiff. class had stated a valid section 1982 claim, nevertheless dismissed the League as a plaintiff, $300 \mathrm{~F}$. Supp. at 230-32, with the result that the case was subsequently prosecuted as Baker v. $F \&$ \& Inv. See Note, Contract Buyers 517 n.6. See note 10 supra. 
ceeded the supply of housing available in the black market and that the defendants exploited this situation by building houses in or adjacent to black areas and sellimg the houses to plaintiffs at prices far in excess of the amounts which white persons paid for comparable residences in neighboring urban areas, and on onerous terms far less favorable than those available to white buyers of similar properties, all in violation of plaintiffs' rights under the Thirteenth and Fourteenth Amendments and the Civil Rights Act of $1866 .^{13}$

The novel element of the claim was that it did not allege that the defendants had engaged in "traditional" racial discrimination of the type involved in Jones; ${ }^{14}$ that is, it contained no allegation that the defendants had treated, "in similar circumstances, a member or members of one race different from the malmer in which members of another race are treated."15 There was no contention that the defendants had utilized different pricing policies in dealing with prospective home buyers of similar financial means but different races. Evidently, both black and white prospective buyers were quoted the same inflated prices with respect to properties situated in the black housing market. Necessarily then, the essence of plaintiffs' theory was that section 1982 does not allow the sellers of property to reap a profit from a dual housing market created by the discriminatory conduct of others. ${ }^{18}$

Chief Judge Swygert, writing for the Seventh Circuit, saw no difficulty in imposing liability under these circumstances; for him, the extrapolation from Jones to Clark was easy. Building upon the Supreme Court's admonition in Jones that section 1982 is designed "to assure that a dollar in the hands of a Negro will purchase the same thing as a dollar in the hands of a white man,"17 he dismissed the defendants' contention that their failure to discriminate in the traditional sense insulated them from section 1982 lability with the statement that it ignored "current realities of racial psychology and economic practicalities." 18 Liability was held to turn on whether defendants' course of con-

13. $501 \mathrm{~F} .2 \mathrm{~d}$ at 327 .

14. See note 4 supra and accompanying text.

15. 501 F.2d at 336, citing Love v. DeCarlo Homes, Inc., 482 F.2d 613, 615 (5th Cir. 1973).

16. The Clark opinion does not specify what relief the plaintiff class was seeking, but the close interrelationship between Clark and the Contract Buyers League case implies that the relief sought im the latter-rescission or reformation of the installment land contracts under which plaintiffs' homes were purchased, plus actual and punitive damages, see S. PlAGER, supra note 12, at 124-25-was sought in Clark as well.

17. 501 F.2d at 330, citing Jones v. Alfred H. Mayer Co., 392 U.S. 409, 443 (1968).

18. 501 F.2d at 331. Chief Judge Swygert also expressed agreement with the conclusion of District Judge Will that "there cannot in this country be markets or profits 
duct resulted in perpetuating residential segregation, regardless of whether blacks and whites similarly situated were actually treated differently. ${ }^{18}$ The court held that when the differential in price and terms between comparable housing units in the black and white markets exceeds the bounds of "reasonableness," a prima facie claim has been stated under the statute. ${ }^{20}$

As an alternate basis for its decision in favor of the plaintiff class, the court held that the evidence offered was also sufficient to make out a prima facie case of traditional racial discimination. ${ }^{21}$ In the court's view, the traditional clefinition of discrimination (unequal treatment of parties similarly situated) was satisfied because three corporations controlled by the defendants were shown to have sold housing roughly comparable to plaintiffs' property to white market buyers at lower prices than plaintiffs were paying. ${ }^{22}$ Whether even this type of conduct can properly be saicl to constitute discrimination in the traditional sense is, however, a difficult question. ${ }^{23}$

The factual allegations advanced before the Fifth Circuit in Love v. DeCarlo Homes, Inc. ${ }^{24}$ closely parallel those of the Clark coinplaint. A plaintiff class composed of installment purchasers of hoines in a subdivision sued the developer of the subdivision and two mortgage lenders for exploiting a market structure tainted by racial discrimination in violation of section 1982. ${ }^{25}$ Again, there was no allegation of traditional discrimination on the part of any of the defendants. ${ }^{26}$ However, subsequent hearings in the Love case revealed a significant distinction between the fact situation there presented and the situation established by the plaintiffs in Clark. The Clark defendants were shown to have charged purchasers of comparable white market housing lower prices than those iniposed upon purchasers in black areas. But in Love

based on the color of a man's skin." Id. at 332, citing Contract Buyers League v. F \& F Inv., 300 F. Supp. 210, 216 (N.D. IIl. 1969). However, a distinction can be drawn between the theories under which the two judges decided in favor of the respective plaintiff classes. See note 32 infra.

19. 501 F.2d at 330-33.

20. Id. at 334 .

21. Id. at 336 .

22. Id. at $336-39$.

23. See text accompanying note 31 infra.

24. 482 F.2d 613 (5th Cir. 1973).

25. Id. at 613 . However, a notable difference between the defendant home builders in Clark and Love is that the fornier absolutely refused to sell property in the black market except through allegedly onerous installment contracts, 501 F.2d at 335-36, while the latter would engage in more conventional financing if the buyer could personally qualify for a mortgage loan, $482 \mathrm{~F} .2 \mathrm{~d}$ at 615 .

26. 482 F.2d at 614 . 
the plaintiffs failed to establish that the defendant home builder, or indeed any other home builder in the Dade County, Florida metropolitan area, had sold homes to the white residential market which were sufficiently comparable to their own that they could serve as the basis for a charge of disparate treatment as to price. ${ }^{27}$

Aside from the evidentiary differences between Clark and Love, Judge Bell of the Fifth Circuit took a somewhat more restrictive view of the scope of section 1982 than did Chief Judge Swygert. His opinion was grounded upon the assumption that the statute, "although applicable to private persons under Jones $v$. Mayer, . . . nevertheless rests on an equal protection premise ...."28 Acknowledging that equal protection concepts clearly proscribe racial discrimination in the traditional sense, the court concluded that a demonstration of such discrimination in the case before it would require a showing that the defendants themselves constructed and sold homes similar to plaintiffs' in the white market at lower prices and upon inore favorable terms. ${ }^{22}$ Plaintiffs' attempt to do so failed because the white subdivision developed by the defendants which plaintiffs sought to compare with their own was comprised of more expensive dwellings and was designed to appeal to a different class of home buyers so that the prices and terms exacted for the two classes of housing could not fairly be compared. ${ }^{30}$ Simce the defendant was not selling similar residential property in the white market, discriminatory pricing could not be proved.

An important observation should be made with respect to the court's definition of traditional racial discrimination in Love, the same defimition employed as the basis for the alternative holding in Clark. ${ }^{31}$ Presumably the court deemed prospective home buyers in either the black or white housing inarkets to be "similarly situated," so that a developer's imposition of higher prices and more burdensoine terms upon buyers in one market than those imposed upon buyers in another would constitute a prohibited discrimination. A strong argument can be made, however, that prospective home buyers who, for whatever reason, are limited to shopping in one of two fairly distimct housing markets are not in fact "similarly situated" to buyers who must shop in the other, and should not be so considered for purposes of applying the traditional formula. The label "traditional" discrimination should perhaps be reserved for instances in which sellers deal differently with

27. Id. at $615-16$.

28. Id. at 616 .

29. Id. at 615-16.

30. Id. at 615 .

31. See text accompanying notes 21-23 supra. 
prospective buyers in the same housing market. Therefore, for the remainder of this Note, the definition of traditional discrimination formulated by the Fifth Circuit to govern its adjudication of the Love case and reapplied in the Clark alternative holding will be referred to as "quasi-traditional" discrimination.

The Love plaintiffs also advanced the theory that a developer of black market housing who does no business in the white market nevertheless violates section 1982 if it can be shown that the prices and terms he imposes upon his black market purchasers are substantially inore burdensome than those which lie probably would impose upon purchasers of comparable white market housing, were he selling in that market. ${ }^{32}$ The Fifth Circuit avoided an in-depth discussion of this theory as a result of the plaintiffs' failure to prove that other developers sold comparable white market housing upon less onerous terms. ${ }^{33}$ With no factual basis for a prediction as to what the defendants' probable business conduct would be if they built for the white market, the court had no choice but to affirm the grant of summary judgment in defendants' favor. It can be argued that proof of such a black-white inarket differential will be all but impossible in most cases because the black and white markets are comprised of types of housing which are fundamentally incomparable, and that the Fifth Circuit's holding in Love therefore announts to predicating liability upon proof of racial discrimination under the traditional or: quasi-traditional theories. ${ }^{34}$ For purposes

32. Id. at 616. The basis for this contention was the decision in Contract Buyers League v. F \& F Inv., 300 F. Supp. 210 (N.D. Ill. 1969). While Contract Buyers League, like Clark, rejected the proposition that traditional racial discrimination must be alleged to state a section 1982 claim, the opinion by Judge Will suggests that he was attempting to construct a variation upon the quasi-traditional formula rather than disregarding both the traditional and quasi-traditional standards entirely. Under the Clark approach, a home builder automatically incurs liability if he sells black market housing at prices unreasonably higher than those being charged by other developers for comparable white market housing. There is no inquiry into the price he would have exacted for such housing if he built for the white market. In contrast, Judge Will seemed to propose the standard alluded to by the Fifth Circuit in Love, i.e., that evidence of prices charged by other developers is primarily relevant as an indication of defendant's probable pricing behavior were it doing business in the white market. This approach is closer to the quasi-traditional theory than the rule enunciated in Clark in that it emphasizes one party's differential treatment, albeit probable differential treatmeut, among at least arguably similarly situated persons. But see text following note 31 supra (discussion of meaning of "parties similarly situated"). For a more detailed analysis of the theoretical distinction between Contract Buyers League and Clark, see Note, Contract Buyers 523 n.17.

33. 482 F.2d at 616.

34. See Note, Discrimination in Housing Under Section 1982, 5 TOLEDO L. REV. 353, 363 (1974). The difficulty of colnputing a "white price" for a given segment of housing units in the black market is discussed in Note, Contract Buyers 524 n.18. 
of analysis, that will be the view taken of Love in the remainder of this Note.

Jones, "Traditional" Racial Discrimination, and the Rules of Clark and Love

A brief overview of Justice Stewart's majority opinion in Jones makes it clear that the case does not compel the result reached in Clark. Jones involved a simple refusal to sell a home to an otherwise qualified black purchaser because of his race; $;^{35}$ the challenged behavior constituted no less than traditional racial discrimination. The Court carefully limited its holding so as not to encompass "discrimination in financing arrangements . . .."36 The only real encouragement offered by Jones to the Clark plaintiffs was its sweeping statements that section 1982 secures "the freedom to buy whatever a white man can buy, the right to live wherever a white man can hive,"37 and that the statute was intended "to assure that a dollar in the hands of a Negro will purchase the same thing as a dollar in the hands of a white man."38

Assuming the truth of the Clark defendants' assertion that they would have charged white buyers of black market residential property the same prices imposed upon black purchasers and imposed similar financing terms, ${ }^{39}$ it is difficult to see how this broad language prohibits them from functioning within a dual market structure which they did not create. The black man's dollar does go as far as the white man's dollar toward the purchase of any of defendants' homes-the problem is that the discriminatory acts of third persons reduce the purchasing power of dollars in both black and white hands when the desired dwelling is part of the black market. Furthermore, the developers' conduct did not restrict black purchasers' freedom to buy homes and live wherever they chose in respect to properties which the developers owned. Had the black plaintiffs desired to purchase white market homes of comparable quality to those which they eventually bought in the black

35. See note 4 supra and accompanying text.

36. 392 U.S. 409,413 (1968).

37. Id. at 443, cited in Clark v. Universal Builders, Inc., 501 F.2d 324, 330 (7th Cir. 1974).

38. 392 U.S. at 443.

39. Acceptance of the Clark developers as totally pristine vis-à-vis attempts to shape the racial composition of the neighborhoods in which they sold residential housing is made more difficult in view of the fact that the defendants in the related Contract Buyers League case were charged with having acquired the properties resold to plaintiffs through the technique of "blockbusting," now prohibited by the Civil Rights Act of 1968, 42 U.S.C. $\S 3604(\mathrm{e})(1970)$. However, in Clark there was no allegation that the defendants engaged in "neighborhood shaping" activities. See notes 80-82 infra and accompanying text. 
market, defendants could not have refused to sell for racial reasons nor exacted more than white market prices and terms. ${ }^{40}$ Those members of the class of home buyers in Clark who were aware of opportunities to buy in the white market nevertheless chose to purchase froin among defendants' black market properties, presumably preferring to live with members of their own race in spite of the accompanying economic disadvantages. Undoubtedly, their reluctance to attempt to break into white neighborhoods, either as individuals or en masse, resulted in part from fear of hostile reactions by white neighbors. However, it is difficult to beheve that they were not also motivated, at least in part, by the desire to reside in a more or less racially homogeneous environment. ${ }^{41}$ This affirmation of the status quo, which in part caused the economic distortions challenged in Clark, must to some degree mitigate the objectionable element of the defendants' conduct.

The Seventh Circuit's answer to these objections was that any conduct which perpetuates residential segregation, and its resultant economic hardships, is the target of section $1982 ;^{42}$ and indeed, it is almost impossible to contend that exploitation of the type practiced by the Clark defendants does not have that effect. However, the court may

40. Conduct of this type would be actionable as traditional discrimination under section 1982. Also available would be claims based on two basic provisions of the Civil Rights Act of 1968, 42 U.S.C. $\$ \S 3604$ (a), (b) (1970), which prohibit, respectively, discriminatory refusals to deal with and the imposition of discriminatory terms in connection with the sale of dwellings. See note 83 infra.

41. This "reluctance to disperse" is recognized in Silverman, Homeownership for the Poor: Subsidies and Racial Segregation, 48 N.Y.U.L. REv. 72, 83-84 (1973). Economists have disagreed about the degree to which the dual market system is perpetuated by a "self-segregating" impulse among blacks. At least one study has attributed the tendency of the black urban population to congregate in old, low quality housing to their generally lower income level and to the numerous barriers, economic and otherwise, which preclude their entry into the white market. See Straszheim, Housing Market Discrimination and Black Housing Consumption, 88 Q.J. EcoN. 19, 21 (1974). However, Professor Straszheim cites two studies which concluded that the self-segregating impulse was a primary factor behind black housing consumption patterns: R. MUTH, CITIES AND Housing 237-40, 284-303 (1969) and Olsen, $A$ Competitive Theory of the Housing Market, 59 AM. Econ. Rev. 612-22 (1969).

It should be recognized that even if one accepts Professor Straszheim's conclusions, they would not fully explain the failure of blacks to break into the white market once the market barriers to which he refers have disintegrated either wholly or in substantial part. In Clark, for example, the evidence suggested that at least some of the plaintiffs could have purchased from the defendants white market housing comparable to that which they eventually bought in the black market, and probably at lower prices. The situation was probably different in Love, however; there the plaintiffs were unable to prove that the defendant builder or any other construction companies in the area had built white market housing substantially similar to their own. Thus, their choice to buy in the black market does not carry with it the implication that they were willing to pay a premium to move into a racially uniform neighborhood.

42. 501 F. $2 \mathrm{~d}$ at 330. 
have been imposing upon the admittedly flexible langauge of the statute its own conception of the types of conduct which Congress could, but has not yet seen fit to, prohibit through the thirteenth amendment's enabling clause. ${ }^{43}$ A true understanding of the scope of the Clark holding comes with the realization that when Chief Judge Swygert stated as a rule of law that "neither prices nor profits-whether derived through well-intentioned, good-faith efforts or predatory and unethical practices-inay reflect or perpetuate discrimination against black citizens," ${ }^{44}$ he, in effect, created a new type of "enterprise liability" which must be borne by all dealers in real property which form part of the black inarket in the Chicago inetropolitan area. ${ }^{45}$ Even if the court's standard of liability - "reasonableness" of price and terms im the black market as compared to those prevailing $i m$ the white market for similar housing ${ }^{46}$ - proves to be a workable one ${ }^{47}$ there is a substantial danger that the new business risk imposed by Clark will drive present and future real property dealers out of the black market, further restricting the supply of housing available to black purchasers. Even assuming that those developers who remain in the black market will comply with the Clark ruling and exact from their buyers prices and terms roughly similar to those imposed upon similarly situated white market purchasers, the overall decrease in the amount of low cost residential housing brought about by the departure of marginal developers could well outweigh any advantages accruing to those prospective purchasers fortunate enough to find affordable residences. Viewed from the standpoint of public policy, the court might have been better advised to let Congress fashion a remedy with such inevitably far reaching effects.

The argument in favor of judicial moderation is strengthened by the fact that the result sought in Clark is compelled by neither Jones and its progeny ${ }^{48}$ nor, in all likelihood, the legislative history of section $1982 . .^{49}$ There is no doubt that a contemporary Congress could reach

43. See note 6 supra.

44. Id. at 332.

45. See Note, Contract Buyers 564 n.156 (critique of this strict liability approach based on prices and terms charged for comparable housing in white inarket).

46. 501 F.2d at 333.

47. See Note, Contract Buyers 524 n.18.

48. E.g., Tillman v. Wheaton-Haven Recreation Ass'n, Inc., 410 U.S. 431 (1973); Sullivan v. Little Hunting Park, 396 U.S. 229 (1969).

49. It is almost inconceivable that the drafters of the statute intended its effect to extend beyond acts of traditional racial discrimination. As observed by Justice Harlan, dissenting in Jones, "[m]any of the legislators who took part in the congressional debates inevitably must have shared the individualistic ethic of their time, which emphasized personal freedoun and embodied a distaste for goverminental interference . . . ." 392 U.S. at 473. 
the activities of the Clark defendants through the thirteenth amendment's enabling clause. ${ }^{.0}$ But to hold that the provisions of a statute originally passed in $1866,{ }^{51}$ or, sub silentio, those of the thirteenth amendment itself, proscribe behavior not constituting racial discrimination in the traditional sense nnay prove to be an unwise mcursion upon the legislative domain.

All of this may seem to support the legal standard enunciated by the Fifth Circuit in Love. The Love court deviated from the traditional theory to formulate a quasi-traditional form of discrimination under which the defendant developer incurs liability if he builds comparable housing for both the black and white markets and imposes different prices and terms upon buyers in each market. But he escapes liability if he builds only for the black market, regardless of the prices and terms he imposes upon his black purchasers as coinpared to those imposed by developers of comparable housing in the white market. ${ }^{52}$ In other words, all the developer need do to avoid section 1982 is confine his operations to the black inarket or, as in Love, build houses in the white market which are not "fit subjects for comparison" because they are "not in similar markets costwise or with the differences attendant in ... . narginal risk financing . . . "\$3 Clearly this result cannot be sanctioned, as "[i]t would mean that the 1866 Civil Rights Act, which was created to be an instrument for the abolition of discrimination, allows an injustice so long as it is visited exclusively on negroes."

Fortunately, in determining the proper scope of section 1982 the courts are not limited to a choice between the shotgun construction adopted by the Clark court and the unevenhanded quasi-traditional theory advanced in Love. The other alternative is to restrict the statute's coverage to conduct which is strictly classifiable as traditional discrimination. True traditional discrimination in the context of a ClarkLove type suit entails disparate treatment of prospective buyers in the same housing market, since buyers in different inarkets are not in fact "similarly situated." Under the traditional approach, a developer who

50. Id. at $438-44$. Three federal courts have already held that the thirteenth amendment affords an adequate constitutional foundation for the "blockbusting" provisions of the Civil Rights Act of 1968. See United States v. Bob Lawrence Realty, Inc., 474 F.2d 115 (5th Cir. 1973); United States v. Mintzes, 304 F. Supp. 1305 (D. Md. 1969); Brown v. State Realty Co., 304 F. Supp. 1236 (N.D. Ga. 1969).

51. Act of April 9, 1866, ch. 31, 14 Stat. 27.

52. 482 F.2d at 615-16. It will be remembered that the plaintiffs in Clark presented evidence that the defendants were engaging in traditional discrimination as defined by the Love court. See text accompanying note 21 supra.

53. Id.

54. Contract Buyers League v. F \& F Inv., 300 F. Supp. 210, 216 (N.D. I1l. 1969). 
owns subdivisions in both markets subjects himself to statutory liability only if he restricts the access of black or white buyers to either subdivision or encourages particular buyers to purchase housing in one or the other subdivision with a view to hastening that subdivision's inclusion in one or the other of the racially defined markets. Before discussing the wisdom of limiting the availability of relief under section 1982 to instances of traditional discrimination, however, it is important to confront a final problem which is created by both the Seventh and the Fifth Circuits' interpretations of the statute-that of formulating a fair and workable remedy.

\section{Remedial Problems Under Clark and Love}

Due to the multitude of individual factors that would bear upon the reformation of a given plaintiff's contract, ${ }^{55}$ discussion must center on rather rudimentary computations of actual damages. The initial computation of damages under eitler the Clark or Love theory of liability would be relatively simple. The plaintiff would be entitled to recover the difference between the price ${ }^{56}$ he agreed to pay and the terms upon which he agreed to pay it and the prices and terms inuposed upon econoumically similarly situated buyers of comparable housing ${ }^{57}$ in the white market during the saine period. ${ }^{58}$ There is no denying that difficulties could arise in proving the components of even this formula. However, they pale in comparison to the problems which are likely to be encountered by courts when they attempt to find a means by which successful plaintiffs and all subsequent purchasers of the property in question can be prevented from reselling the property at the black market price and themselves realizing an unlawfully high profit through the dual market system. Plainly it would subvert the

55. According to the Clark opinion, "[t]he statute does not mandate that blacks are to be sold houses at the exact same price and upon the exact same terms as are available to white citizens. Reasonable differentials due to a myriad of permissible factors can be expected and are acceptable." 501 F.2d at 333.

56. In practice, the computation of "price" would take into account the transactional costs which accompany both deed-mortgage and installment sales transactions. For an interesting comparison of transactional costs as between these two types of transactions, see Mixon, Installment Land Contracts: A Study of Low Income Transactions, With Proposals For Reform and a New Program to Provide Home Ownership in the Inner City, 7 Houston L. Rev. 523, 529-35 (1970).

57. The Clark court indicated that similarity of "communal amenities such as transportation, schools, churches, and quality of neighborhood" should be considered in determining whether particular residential units in the black and white markets are comparable. 501 F.2d at 335 .

58. Although the procedural posture of Clark did not necessitate a discussion of reinedies, the opinion does not foreclose an award of damages computed according to this formula. See id. at 333 . 
court's decision if the original plaintiffs in a Clark-Love type suit were allowed to reap the profit which their vendors had been forced to relinquish, and the same unfairness would result when any subsequent owner of the property sold at the black market price. While the original Clark-Love plaintiffs could be enjoined froin reselling at an unreasonable price or upon overly burdensome terms, ${ }^{50}$ devising a legal mechanism to prevent exploitative pricing by all subsequent owners would present great problems.

Two priorities would necessarily weigh heavily in framing a proper reinedy. The first, of course, would be the protection of subsequent buyers from section 1982 violations, whether based upon the Clark or Love theory of liability. The second would be maintenance of an economic environment in which land can be more or less freely transferred without undue risk of hitigation. Sucln a fluid market would obviously favor even black market purchasers by freeing the limited supply of available housing and encouraging low cost housing developers to build for the black market. Thus soine means of protecting sellers of new and used residential housing from specious, vexatious litigation would have to be built into the court's remedy.

Initially, it is clear that subsequent sellers could be sued by their purchasers or prospective purchasers-black or white-under section 1982. At least one lower court decision, Walker $v$. Pointer, ${ }^{60}$ has convincingly reasoned that despite its thirteenth amendment underpinnings, the statute affords relief for even nonblacks who suffer "from the wrong the amendment was created to cure." ${ }^{11}$ In cases governed

59. Injunctive relief is available under section 1982. See Jones v. Alfred H. Mayer Co., 392 U.S. 409, 414 n.13 (1968).

60. 304 F. Supp. 56 (N.D. Tex. 1969).

61. Id. at 58. The court cited three reasons for reaching this result: (1) it did not conflict with Jones; (2) similar fourteenth amendment cases supported it; (3) a contrary result would conflict with the equal protection elements of fifth amendment due process. Id.

The last argument is by far the most interesting of the three, and the Walker court's resolution of the problem appears sound in view of the legislative history of section 1982 and as a matter of harmonizing potentially contradictory constitutional provisions. The issue is whether the statute's thirteenth amendment origin prohibits all citizens except blacks (or, arguably, members of other minority groups who were oppressed to the point of slavery) from suing for its violation, and whether this limitation conflicts with notions of equal protection. The source of this equal protection component would not be the fourtecnth anendment, which is directed solely at the states, but the due process clause of the fifth amendment, which has been held to incorporate the equal protection standard. Cf. Bolling v. Sharpe, 347 U.S. 497 (1954). However, in order to sinplify discussion, equal protection will be considered as at least "emanating from" the fourteenth amendinent.

The Supreme Court has attached significance to the fact that the Civil Rights Act of 1866, the statute from which section 1982 derives, and the joint resolution which later 
by the legal rules propounded in Clark or Love this principle presumably would support mvocation of the statute by white purchasers against black sellers in that the latter would be feeding off the racially tamted dual inarket system to the same extent as white sellers.

The general availability of the statute against subsequent sellers does not, however, of itself offer a great deal of protection to future buyers. As individuals, many of them could not be expected to bear the cost of initiating original actions against their immediate sellers. The class action device would be of limited utility for two reasons. First, in inost cases there would not be a common seller, or group of sellers, who could be sued on the basis of a more or less uniform course of dealing with a large number of buyers; every individual who bought from the owner of a home in a subdivision, for example, would necessarily have to inake out his claim on the facts of the isolated transaction between his seller and himself. This might well prevent the class members from satisfying the requirement of Rule 23(b)(3) of the Federal Rules of Civil Procedure that common legal and factual questions predominate over those "affecting only individual members." Secondly, in order for the suit to be economical, hoine buyers who believed they had been overcharged inight have to wait a number of years to find a sufficiently large number of other persons willing to bear the

became the fourteenth amendment were enacted during the same session of Congress, see Hurd v. Hodge, 334 U.S. 24, 31-33 (1948), and it has also been noted that the 1866 Act was re-enacted in 1870 pursuant to the fourteenth amendment, see Tillman v. Wheaton-Haven Recreational Ass'n, 410 U.S. 431, 439-40 n.11 (1973). The conclusion to be drawn is that the statute almost inevitably incorporates equal protection concepts derived from the fourteenth amendment. Even assuining, however, that the statute's thirteenth amendment origins would be deeined controlling, the two amendinents should, if possible, be construed harmoniously so as to give effect to the provisions of both. Cf. Cohens v. Virginia, 19 U.S. (6 Wheat.) 264, 393 (1821). It would appear that recognizing the right of nonblacks to sue for thirteenth amendment violations would do no violence to the amendment's policy of eliminating all "badges and incidents" of slavery. This is certainly the best argument in favor of the result in Walker. And indeed, it may be the only means of reconciling the two annendments, unless the courts found the thirteenth amendinent policy of removing the former effects of slavery an "overriding justification" sufficient under the fourteenth to outweigh disparate treatment of parties similarly situated. Compare McLaughlin v. Florida, 379 U.S. 184, 192 (1964), with De Funis v. Odegaard, 416 U.S. 312, 331-44 (1974) (Douglas, J., dissenting). See also Note, The New Thirteenth Amendment, supra note 2, at 1294, 1318 (1969).

Fimally, even if one were forced to conclude that the amendments were irreconcilable, the policy of the fourteenth (incorporated into the fifth) should prevail because the fourteenth was ratified after the thirteenth and as such constitutes the latest expression of Congress. The argument would not be entirely without difficulty, however, in view of the rule of construction favoring specific provisions over general ones.

62. FED. R. Crv. P. 23(b)(3). It is unlikely that most groups of aggrieved home buyers could prosecute class suits pursuant to subdivisions (1) or (2) of subsection (b). 
expense of joining them in a class action, thus giving rise to statute of limitations complications. ${ }^{63}$ Therefore, the bulk of the responsibility for protecting the rights of buyers subsequent to the plaintiffs in the original Clark-Love type suit would fall upon the district court whicl adjudicated that suit.

The first remedial alternative likely to be considered is one commonplace in civil rights litigation: retention of equitable jurisdiction over the property in question for the indeterminate future. While this would reduce the start-up costs of litigation which would normally be borne by subsequent buyers who in good faith believed themselves to have been victimized by their sellers, it could operate as an imvitation to subsequent buyers who did not make the bargains they desired to rush into federal court for an adjustment of their prices and terms of purchase. Regardless of their chances of success, the bare possibility that they might bring such actions could have a chilling effect upon an otherwise relatively unrestricted market in residential housing.

A more suitable remedy, one whicl could reduce the potential for narket-restricting litigation while still deterring exploitative pricing, can be formulated from the model of the common law covenant running with the land. The common law concept would have to be modified in ways not currently recognized under the laws of most states in order for it to have real utility as a remedy in suits like Clark and Love. ${ }^{64}$ However, in Sullivan v. Little Hunting Park ${ }^{65}$ the Supreme Court interpreted section three of the Civil Rights Act of $1866,{ }^{66}$ now codified as 42 U.S.C. $\$ 1988,{ }^{67}$ as authorization for courts granting relief under section 1982 to look to both federal and state law in fasl-

63. See Baker v. F \& F Inv., 420 F.2d 1191 (7th Cir.), cert. denied, 400 U.S. 821 (1970). The court of appeals affirmed the district court's ruling in the Contract Buyers League cases that the respective plaintiff classes had to be redefined to exclude home owners whose installment purchase contracts had terminated inore than five years before the actions were initiated.

64. See notes 73-76 infra and accompanying text.

65. 396 U.S. 229 (1969).

66. Act of April 9, 1866, ch. 31, 14 Stat. 27.

67. The jurisdiction in civil and criminal matters conferred on the district courts by the provisions of this chapter and Title 18, for the protection of all persons in the United States in their civil rights, and for their vindication, shall be exercised and enforced in conformity with the laws of the United States, so far as such laws are suitable to carry the same into effect; but in all cases where they are not adapted to the object, or are deficient in the provisions necessary to furnish suitable remedies and punish offenses against law, the common law, as modified and changed by the constitution and statutes of the State wherein the court having jurisdiction of such civil or criminal cause is held, so far as the same is not inconsistent with the Constitution and laws of the United States, shall be extended to and govern the said courts in the trial and disposition of the cause, and, if it is of a criminal nature, in the infliction of punishment on the party found guilty. 42 U.S.C. $\$ 1988$ (1970). 
ioning federal common law remedies which best serve the policy of the statute. $^{68}$ The only limitation the statute places upon the use or formulation of federal common law in shaping remedies under section 1982 is its proviso that the common law applied not conflict with the constitution or statutes of the state where the particular district court sits. ${ }^{69}$ It can be argued that imposing a real covenant regulating the price of land amounts to more than the utilization of an orthodox judicial remedy. Nevertheless, nothing in the statute implies that a legal device which has been employed in relatively limited circumstances under state or the general common law, such as the real covenant, cannot be utilized to provide the fullest possible relief in section 1982 actions. $^{70}$

A brief comparison of the basic covenant which would be required to protect subsequent purchasers in Clark-Love type cases witl the prevailing law on covenants running with the land reveals a number of significant discrepancies. The necessary components of a covenant of the type contemplated would be (1) a promise by the buyer of the land not to resell upon more onerous terms than those currently imposed upon economically similarly situated buyers of comparable housing in the white market, and (2) some mechanism for conveying the amount of any unreasonable differential imposed from the offending seller to the victimized buyer.

At the outset it should be noted that characterizing the covenant as a third-party beneficiary contract made between the parties to the original suit in favor of all subsequent buyers of the property in question would be of limited utility once the property passed beyond the first subsequent buyer. The lack of an identifiable beneficiary at the time the covenant was made would not invalidate the contract; ${ }^{71}$ lowever, before a subsequent buyer from any of the original co-plaintiffs could be bound by the promise not to overcliarge future buyers, that subsequent buyer would himself have to assume the promise, either expressly or impliedly. The mere purchase of the property probably

68. 396 U.S. at 240. See Note, Contract Buyers 537-39. The author postulates that the "common law" which section 1988 allows to be incorporated into civil rights remedies is the federal or general common law promulgated by the federal judiciary during the regime of Swift v. Tyson, 41 U.S. 1 (1842). This interpretation of the statute would allow modern courts to disregard state decisional law which frustrates the purpose of section 1982. See Note, Contract Buyers 543-45.

69. See note 67 supra.

70. For an expansive interpretation of the term "remedies" as used in section 1988, see Brazier v. Cherry, 293 F.2d 401, 408 (5th Cir. 1961). It should be noted, however, that section 1988 is of no avail to plaintiffs who seek to import into federal law entire state law causes of action. See Moor v. County of Alameda, 411 U.S. 693, 703-04 (1973).

71. See 4 A. Corbin, Corbin on Contracts $\$ 781$ (1951). 
would not operate as such an assumption. ${ }^{72}$ Therefore, in most cases the duty not to overcharge would fall only upon the original co-plaintiffs.

The first and greatest difficulty with the contemplated covenant is that it would constitute a direct restraint upon alienation, usually void under the general common law and the statutes of most of the states. ${ }^{73}$ The argument in defense would be that since section 1988 allows courts to combime state, federal, and general common law to effectuate the purposes of the civil rights laws, the authority of section 1982, and inferentially the thirteenth amendment, should take precedence over firmly entrenched state policy in the process for formulating a proper remedy. Assuming arguenclo that this argument would prevail and that the policy against direct restraints was not embodied in either the constitution or statutes of the state where the rendering court was located, ${ }^{74}$ the next task would be to construct an effective covenant which at least nominally satisfied the four generally recognized characteristics of a valid real covenant: (1) that it be in writing; (2) that the parties intend that it run with the land; (3) that the promise "touch or concern" the land; and (4) that privity of estate exist between the parties thereto. ${ }^{75}$

The prototypal covenant running with a fee simple is created when a seller, desiring to secure some benefit for himself and future owners of the remainder of a large tract froin which the property in question is being sold, exacts as part of the consideration for the sale a promise from the buyer that he, his heirs and assigns, will do or refrain from doing specified acts with respect to the property purchased. The burden of the covenant runs with the property purchased and the benefit runs with the property retained. Such a covenant generally "touches and concerns" both the benefited and burdened estates, and

72. Compare Nicholson v. 300 Broadway Realty Corp., 7 N.Y.2d 240, 164 N.E.2d 832, 196 N.Y.S.2d 945 (1959), with 4 A. CORBIN, supra note 71, 808 (1951), discussing Maher v. Cleveland Union Stock Yards Co., 55 Ohio App. 412, 9 N.E.2d 995 (1936). See also Restatement of Property \$ 541, comment $c$ (1944).

73. See, e.g., Maynard v. Polhemus, 74 Cal. 141, 15 P. 451 (1887); Kershner v. Hurlburt, 277 S.W.2d 619 (Mo. 1955); De Peyster v. Michael, 6 N.Y. 467 (1852); Dunlop v. Dunlop's Ex'rs, 144 Va. 297, 132 S.E. 351 (1926). See generally 6 R. Powel, The LAW OF REAL ProperTy If 842, at 13 (1958), noting that although restraints which require sharing of the proceeds of land do not forbid alienation entirely, they are generally held void because they are "bound to create hesitancy in selling . . . ."

74. See text accompanying note 64 supra.

75. See C. Clark, Real Covenants and Other Interests Which "Run With LAND" 94 (2d ed. 1947). It is important to note that while Judge Clark himself did not agree with the characterization of "privity" included in the text, i.e., as between the parties to the covenant, he admitted that "if mere frequency of judicial statement is to govern, it . . . would seem to be the current rule of law." Id. at 116. 
privity of estate exists between buyer and seller because the burdened estate is carved out of the benefited one.

A covenant of the type contemplated here would deviate from this model in that the real benefit of the buyer's promise would run not to the seller, the other party to the covenant, but to an umidentified subsequent buyer. Furthermore, both benefit and burden seemingly would be assumed by each subsequent buyer at the date of purchase; ownership would confer upon him the present "benefit" of having a potential claim for overcharge against his seller, but would also impose the latent "burden" of having to account for such an overcharge to his subsequent buyer after divesting himself of ownership. In sum, a covenant which purported to operate in this "leapfrog" fashion would be so far outside conventional concepts of real covenants ${ }^{76}$ as to amount

76. The Restatement of Property does not sanction "running benefits" where the promise does not benefit the owner of the land in his "use" of it. RESTATEMENT of PrOPERTY $\$ 543(1)$ (1944). An owner's claim for reimbursement of a portion of an excessive purchase price does not respect his "use" of the land as that term is defined by the Restatement. Id. $\$ 543(2)$ \& comment. Neither does the Resiatement contenplate covenants in gross, i.e., covenants under which both the benefit and the burden do not attach to and run with separate, concurrently owned pieces of realty. See id. $\$ \S 535,537$ \& couninents $a, h, 547$.

Judge Clark is more liberal. He cites with approval cases where the running benefit was the right to receive cash payinents which rendered the owner's legal interest in the property more valuable. See C. CLARK, supra note 75, at 97, 99-100 \& nn. 19, 20. He also sees no reason to disallow covenants where either the burden or benefit are in gross. Id. at 106-07. None of the cases he cites, however, involved successive assumption of the benefit and the burden of a covenant by the same party, determined by his term of ownership of the property involved, aud it is unlikely that a covenant of the type contemplated would be approved.

However, a rather circuitous mechanism can be envisioned which would be inore consistent with conventional theory and yet yield the desired result. In contrast to the "leapfrog" covenant described in the text, the covenant could be drafted so that the "benefit" of having a claim for overcharge would be retained by one person and the "burden" of having to resell the property at a reasonable price passed along to each successive buyer during his term of ownership. The permanent beneficiary would be the original seller of the property, i.e., the party to whom the plaintiff buyer in the ClarkLove type suit inade the promise to resell upon reasonable terms.

This procedure would coine much closer to satisfying the traditional requirements for real covenants than the "leapfrog" method. Despite the fact that a burden of this type would not concern the owner's "use" of his land as required by the Restatement, see Restatement of Property $\$ 537$ \& comment $b$ (1944), at least one noted coinmentator has stated that a running burdeu need do no more than render the owner's legal interest in the property "less valuable." See C. CLARK, supra note 75, at 97; accord, 165 Broadway Bldg., Inc. v. City Investing Co., 120 F.2d 813 (2d Cir.), cert. denied, 314 U.S. 682 (1941). That requirement would be inet if the covenant were drafted so as to bind each successive owner while he owned the land by forbidding him to contract for its resale at unreasonable terms. Similarly, keeping the benefit in the original seller rather than attempting to pass it down the chain of prospective buyers could be advantageous. Such a covenant in gross, in which the benefit does not accrue as a re- 
to a judicially imposed-rather than a hybrid-remedy constructed from federal, state, and common law.

The seriousness of the remedial problems lurking in Clark-Lovetype actions can only reflect negatively upon the substantive legal standards which engendered them. The greater the extent to which conventional doctrine must be stretched in order to provide a thoroughgoing remedy, the greater becomes the suspicion that the responsibility for formulating that remedy properly rests with the legislature. Yet a inodified covenant running with the land may be the only mechanism which satisfactorily reconciles the competing priorities of section 1982 and of maintaining a relatively fluid housing market. The prospective buyer of property encumbered by a section 1982 covenant probably would have less reason to concern himself over the possibility of having to defend a frivolous suit upon resale than if the district court which rendered judgment in the initial Clark-Love-type suit retained jurisdiction over the property, since a disappointed subsequent buyer might well be unwilling to bear the expense of initiating suit if his claim were not bona fide. On the other hand, an imdividual interested in acquiring the property could not ignore the fact that the language of the covenant not only would alert a subsequent buyer to his statutory rights but also, in effect, state his potential claim before his eyes. The covenant could encourage self-regulatory conduct by sellers in setting their terms without creating a counterproductive "chilling effect" upon the residential housing market. If the imposition of liability in the first instance under the rules of law stated in Clark and Love is to be defended at all, it must be bolstered by some remedial device similar to the proposed section 1982 covenant.

It appears, then, that the traditional theory of discrimination enbodies the correct standard of liability under section 1982. In cases like Clark and Love it would embrace any course of dealing through which prospective buyers in the same market were treated unequally.

sult of present ownership of a piece of realty, has been approved by Judge Clark. The Restatement is contra.

Assuming that this basic covenant would be validated, the obvious next step would be to devise a means by which any differential theoretically recoverable thereunder could be transferred from the original seller to the party aggrieved, the subsequent buyer. One solution would be to attach to the covenant a counter-promise by the original seller to the original buyer that the seller would enforce the covenant and pay any amounts received thereunder from any of the buyer's successors in interest to the victim of the proscribed overcharge as a third party clonee beneficiary. The contract would be valid despite the lack of a presently identifiable beneficiary. See note 71 supra and accompanying text. Suit on the contract, and thereby on the covenant, could be initiated by any aggrieved buyer. See A. CoRbIN, supra note 71, § 810 (1951). 
It would not support either the Clark "perpetuation of segregation" standard nor the quasi-traditional theory advanced in Love. Of course, adopting an analytical approach which denies recovery for activities which exact an exorbitant profit fron the prevailing dual market system does not make those activities any nore palatable. ${ }^{77}$ Nevertheless, state law sanctions may be available when a developer's conduct approaches overreaching or outright fraud. ${ }^{78}$ Furthermore, the suggested analysis in no way diminishes the potency of section 1982 for dealing with activities which foster further development of residential segregation.

Under the traditional theory, statutory liability will extend to most situations in which builders or other sellers of real property, through their conduct toward prospective buyers, attempt to shape to their own ends the racial composition of the neighborhoods in which the properties are located. Proscribed activities would of course include direct and indirect refusals to deal on racial grounds. ${ }^{79}$ However, hability could also be predicated upon conduct toward buyers which is aimed at "guiding" newly constructed housing into one or the other of the racially delineated housing markets. ${ }^{80}$ It is clear, for example, that

77. As stated by the trial judge in Clark, "counsel for the plaintiffs have not painted a pretty picture of the defendants, but that picture is a picture of exploitation for profit, and not racial discrimination." Clark v. Universal Builders, Inc., 501 F.2d 324, 327 (7th Cir.), cert. denied, 43 U.S.L.W. 3349 (Dec. 16, 1974).

78. See note 92 infra and accompanying text.

79. In covering such refusals to deal, section 1982 would overlap section 804 of the Civil Rights Act of 1968, 42 U.S.C. $\$ 3604$ (1970). However, section 1982's utility remains even in fact situations governed by the 1968 Act since actions under the latter are limited by the "private home" exemption of section 803, id. $\$ 3603$ (b) (1970), and the short 180 day limitations period imposed by sections $810(\mathrm{~b})$ and $812(\mathrm{a})$, id. $\S \S$ 3610 (b), 3612(a) (1970). Federal courts have held that section 1982 operates independently of both the section 803 exemption, see Bush v. Kaim, 297 F. Supp. 151, 161 (N.D. Ohio 1969), and the limitations provisions, see Hickman v. Fincher, 483 F.2d 855 (4th Cir. 1973).

80. The market toward which a seller might be tempted to "guide" new housing units would be determined largely by the location and quality of the housing, and thus by the class of persons economically situated to purchase it. For example, the developer of a large subdivision of inexpensive homes in a racially mixed section of a city could decide to boost his profit by mjecting all or most of the subdivision into the undersupplied black housing market; therefore, he would be likely to discourage prospective white buyers with gratuitous and perjorative statements (not inade to prospective black buyers) that the subdivision had already attracted a large nunber of blacks and would probably be "taken over" within a few years. In contrast, the builder of expensive homes who did not want to lose prospective white purchasers because of the presence of black homeowners conld fortify his position in the white market by volunteering to prospective black buyers infornation about the racial hostility felt by present and probable future white hoineowners. For a discussion of the utility of the traditional theory of racial discrimination in distinguishing between this type of conduct and objective assessments 
when the motive behind a seller's representations or other conduct toward his buyers is to place the housing in question in one of the racially distinct housing inarkets, those representations will almost of necessity vary as between buyers of different races. Such disparate treatment of parties similarly situated-in this case, black and white prospective buyers of the same residential unit-would constitute racial discrimination in the traditional sense and thus violate section 1982.

On the other hand, if a seller's respresentations concerning a subdivision's present or probable future racial composition do not vary qualitatively ${ }^{81}$ as between members of different races, his conduct should not be actionable under the statute. Sellers, therefore, could make objective assessinents of the racial and economic characteristics of particular neighborhoods, ${ }^{82}$ and buyers would remain free to indulge their own racial prejudices in acting upon such representation. In sum, developinent of residential patterns based on race which does not result froin sellers' disparate treatment of buyers because of race would not be disturbed. ${ }^{83}$

made by sellers to buyers concerning the racial and economic makeup of neighborhoods, see notes 81-82 infra and accompanying text.

There is no authority for imposing section 1982 liability upon real property sellers who attempt to "guide" residential units in the manner described, either individually or en inasse. However, the district court in Contract Buyers League by implication held that the "blockbusting" technique, through which some of the defendant-purchasers were alleged to have obtained at unduly low prices residences which were subsequently resold to the plaintiffs, would violate section 1982. A glance reveals that "blockbusting" is the converse of "neighborhood shaping"- - the blockbuster makes race-related representations to sellers in order to depress the price at which they will sell, while the "neighborhood shaper" makes such representations to buyers with a view to placing the housing unit in either the black or white market and thereby increasing the prices he will be able to extract froin buyers. "Blockbusting" for profit is now expressly prohibited by section 804(e) of the Civil Rights Act of 1968, 42 U.S.C. $\$ 3604$ (e) (1970).

81. It is obvious that the measure of "variation" between statenents made to black and white purchasers could be minimal or nonexistent, and yet a seller could still be motivated by a discriminatory animus aimed at shaping a neighborhood's racial composition for his own profit. However, in cases where evidence outside of the substantive content of the seller's representations suggest an intent to "shape a neighborhood," courts could hold him to a standard of minimal variation between representations inade to buyers of different races in order to bring the traditional theory of discrimination and section 1982 into play.

82. Cf. United States v. Mintzes, 304 F. Supp. 1305, 1312 (D. Md. 1969), holding that section 804(e) of the Civil Rights Act of 1968, 42 U.S.C. $\$ 3604(\mathrm{e})$ (1970), does not proscribe honest answers made by real estate brokers in response to owners' questions concerning the racial composition of their neighborhoods. But cf. Brown v. State Realty, 304 F. Supp. 1236, 1241 (N.D. Ga. 1969). See generally Note, Blockbusting, 59 GEo. L.J. 170, 186-87 (1970).

83. Simce particular emphasis has been placed upon the remedial difficnlties likely to be encountered under the Clark and Love constructions of section 1982, a short discussion of the types of relief available under the traditional theory is in order. In cases 


\section{Conclusions and Alternatives to Extending Section 1982 Beyond Traditional Concepts of Racial Discrimination}

It has been the thesis of this Note that the courts which decided the Clark and Love cases constructed rules of law which extend section 1982 liability too far, and that their lack of moderation will be evidenced by the difficulties they are bound to encounter in attemptimg to frame suitable remedies. However, none of the foregoing commentary has been intended to minimize the imequity or severity of the situations with which the plaimtiffs in Clark and Love were faced. Though it has been recommended that section 1982 be construed to forbid instances of traditional racial discrimination only, it lias also been expressly assumed that the traditional theory encompasses most if not all activities which foster the extension of the dual market system, ${ }^{84}$ ranging from blatant or subtle refusals to deal to conduct aimed at "shaping" the racial composition of neighborhoods for profit. Some comfort can be drawn both from the fact that the Civil Rights Act of 1968, in conjunction with section 1982, conceivably could be invoked against parties as diverse as individual sellers of liomes and large savings and loan institutions, and that the statutes utility lias been increased by judicial recognition of nonblacks as proper plaintiffs under both. ${ }^{85}$

of racially motivated refusals to deal, the usual remedy would be a permanent injunction against the acts which violated section 1982. Cf. 42 U.S.C. $\$ 3612$ (c) (1970). See note 59 supra. Framing proper remedies against the "neighborhood shaping" seller would be more difficult in that he may already have induced or discouraged a sufficient number of purchases in the neighborhood to place it in one or the other of the housing markets. A permanent imjunction forbidding the seller froin attempting to shape neighborhoods in the future would be helpful, but could not afford relief to many aggrieved persons, e.g., black buyers who shopped in the white market but eventually bought in the black market because a white-market seller's statements convinced them that they could not realistically live in the homes he was selling due to racially prejudiced white neighbors. See note 80 supra. For these litigants relief would have to come through money damages and/or reformation of the installment contracts under which they had purchased. The computation of damages would necessarily entail a determination of the difference between black and white market prices. The difficulty of presenting evidence from which black and white market prices and terms could be established might be great. However, some measure of imprecision would seem acceptable in the course of vindicating the fundamental rights secured by section 1982. Unlike the serious remedial infirmities, which accompany both the Clark and Love interpretations of the statute, imprecision on this scale would not constitute grounds for calling into question the validity of the eutire traditional theory of hability.

84. For an explanation of the near impossibility of direct suits by homeowners in the position of the plaintiffs in Clark and Love against the flock of individuals and/or institutions which conceivably contributed toward creating the existing dual market system, see Note, Contract Buyers 526-30.

85. The relevant decision under section 1982 is Walker v. Pointer, 304 F. Supp. 56 (N.D. Tex. 1969). See notes 60-61 supra and accompanying text. With respect to sec- 
Nevertheless, the large number of private and governmental entities which incrementally contribute to the extension of the dual market system over relatively long periods of time may make it impossible for even a diverse class of plaintiffs to obtain adequate relief against the numerous entities contributing to the discriminatory action. ${ }^{86}$ Furthermore, the Government has largely confined its enforcement activities under section 813 of the Civil Rights Act of $1968^{87}$ to instances of discrimination by the immediate vendors of residential units, ${ }^{88}$ leaving undisturbed the activities of financial imstitutions and government agencies. Finally, the advisability of attempting to force residential integration upon the races is open to question. One commentator has been at least partly correct in arguing that both state and federal fair housing statutes, aside from being imcomplete in coverage and weak in enforcement measures, take the wrong approach to the problein of middle class resistance to residential integration by attempting to coerce the white community into compliance. ${ }^{89}$ Similarly, the reluctance of some black families to move into predominantly white neighborhoods because they prefer to live with inembers of their own race, and the probability that this reluctance perpetuates and spreads the dual market system, cannot be ignored. ${ }^{90}$

The conclusions to be drawn from this are threefold. First, attempts to extend the dual market system can and should be attacked by private hitigants or the Government under section 1982 or the 1968 Civil Rights Act; second, to the extent these statutory remedies are inadequate to the task, Congress and the state legislatures should improve their effectiveness; and third, since section 1982, properly construed, is not a proper tool for attacking the existing dual market system, Congress and the state legislatures should take steps to abolish the existing system or to make its effects less onerous. The most productive solutions to problems encountered by black market honie buyers may be those which aim at softening the detrimental effects of the dual nuarket structure, rather than attempting to eliminate it altogether.

A number of legislative and judicial renedies capable of rendering

tion 810(a) of the 1968 Civil Rights Act, 42 U.S.C. $\$ 3610$ (a) (1970), see Trafficante v. Metropolitan Life Ins., 409 U.S. 205 (1972).

86. See Silverman, supra note 41 , at 78-97.

87. 42 U.S.C. $\$ 3613$ (1970).

88. See, e.g., United States v. West Peachtree Tenth Corp., 437 F.2d 221 (5th Cir. 1971) (apartment operators); United States v. Grooms, 348 F. Supp. 1130 (M.D. Fla. 1972) (nobile home park operator:); United States v. Luebke, 345 F. Supp. 179 (D. Colo. 1972) (realtors).

89. See Silvermau, supra note 41 , at 97-100.

90. See note 41 supra and accompanying text. 
the status quo more bearable are currently available at both the state and federal levels. It is significant that none of them directly attacks the dollar differential im prices and terms between black and white markets. State law actions based on fraud or unconscionability, for example, erect standards of permissible conduct by sellers in commercial transactions. However, the fact that many state courts do not allow the invocation of fraud or unconscionability except in relatively limited and extreme circumstances ${ }^{21}$ may render these common law causes of action too inflexible to be genuinely effective against the more covert and subtle sales techniques practiced by some sellers of residential property. More promising are those state statutory provisions aimed at "civilizing" the easily abused installment land contract.92 If more states adopted regulations similar to these, low income families could utilize the installment contract method of purchase, which eliminates many of the transactional costs accompanying deed-mortgage purchases, ${ }^{93}$ without undue fear of exploitation.

Of course, the most direct means by which poor families can overcome the vicissitudes of the dual market is for the state or federal government to partly or wholly subsidize their home purchases. Congress provided such a program through section 235 of the Housing and Urban Development Act of $1968,{ }^{94}$ which authorizes the Department of Housing and Urban Development (HUD) to insure mortgages and "to make interest-assistance payments on behalf of the purchaser directly to his mortgagee." ${ }^{\text {55 }}$ State or federal direct subsidy programs may prove to be the most popular legislative response to the actual price effects of the dual market, since legislatures may feel that they should

91. An astonishing illustration of the types of conduct which does not give rise to claims for fraud or unconscionability under Illinois law may be found in Contract Buyers League. See 300 F. Supp. at 225-28. One commentator offers as his central thesis the view that the courts should adopt a standard of "racial unconscionability" extending beyond traditional notions of discriminatory conduct when dealing with cases like Clark and Love. See Note, Contract Buyers.

92. One commentator, noting with general approval the regulatory schemes adopted by Maryland and California, has suggested that tight controls be applied to a number of nonprice contract terms. See Mixon, supra note 56, at 565-74. These controls include mandatory contract terms designed to protect the installment purchaser's accrued equity froin his seller's mortgage creditors-terms providing for equal monthly payments (eliminating so-called "balloon notes") and delivery of a deed upon the payment of a given percentage of the purchase price. Id. at 568-74.

93. See id. at 526-35.

94. 12 U.S.C. $\$ 1715(\mathrm{z})(1970)$.

95. Silverman, supra note 41 , at 73 . Although the program has been criticized as perpetuating residential segregation, see id. at 82-97, and has not been operated so as to benefit "the abject poor," available data indicates that substantial numbers of black families have taken advautage of it prior to January 5, 1973, the date of a Presidential moratorium upon any additional funding for the program. Id. at 72, 77-80. 
not tamper with the central element of any market system, price, even though the system has been. distorted by discriminatory conduct, but rather should content themselves with ameliorating the system's socially undesirable effects.

In any event, whatever the character of Congress' and the state legislatures' responses to the laardships created by the dual market system, it is difficult to refute the view that the responsibility for eliminating its price effects lies with them rather than the courts. Undoubtedly, the broad language of the thirteenth amendment can be read to authorize an extension of the coverage of its implementing statutes, including section 1982, to the discriminatory pricing activities challenged in Clark and Love; the amendment's abolition of the "badges and incidents of slavery" has already been utilized by Congress in section 804(s) of the 1968 Civil Rights Act ${ }^{98}$ to proscribe conduct which does not constitute traditional racial discrimination. ${ }^{97}$ But for the courts to divine a congressional intention to forbid nontraditional acts of discrimination in a statute passed over a century ago, particularly where such a determination is likely to have unpredictable and far-reaching economic repercussions, appears to be ill-advised, notwithstanding the syinpathetic positions of particular plaintiffs. The unavoidable remedial problems which would arise further inveigh against the wisdorn of such an expansion of the scope of section 1982. The better approach for both the Seventh and Fifth Circuits would have been to formulate rules of law which adhered faithfully to the traditional theory of racial discrimiation, leaving to Congress and the state legislatures the elimination of the inequities which plaintiffs in Clark and Love brought before the public eye.

96. 42 U.S.C. § $3604(\mathrm{e})$ (1970).

97. See note 50 supra and accompanying text. 